Функционально-ориентированные и модульные технологии
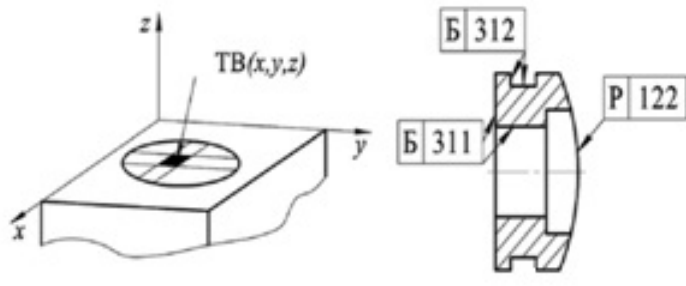

УДК 621.791.927.5

DOI: 10.30987/article_5d6518cdbd63b1.92756726

Е.Н. Ерёмин, д.Т.Н., А.С. Лосев, инженер, И.А. Пономарев, инженер, С.А. Бородихин, инженер (Омский государственный технический университет (ОмГТУ),

644050, г. Омск, Проспект Мира, 11)

E-mail: weld_techn@mail.ru

Технологическое повышение адгезионной износостойкости деталей, наплавленных хромистой порошковой проволокой, легированной комплексом соединений бора и азота *

\begin{abstract}
Показано, что структура металла, наплавленного порошковой проволокой состава $15 \% \mathrm{Cr}-0,5 \% \mathrm{~B}_{4} \mathrm{C}-0,5 \% \mathrm{BN}-2,5 \% \mathrm{Ti} B_{2}-1,0 \% \mathrm{ZrB}{ }_{2}$, представляет собой мартенситную матрииу с боридной эвтектикой $(\mathrm{Fe}, \mathrm{Cr})_{2} \mathrm{~B}$, карбоборидов типа $(\mathrm{Fe}, \mathrm{Cr})_{7}(\mathrm{C}, \mathrm{B})_{3}$ и нитридов $\varepsilon-(\mathrm{Fe}, \mathrm{Cr})_{2-3} \mathrm{~N}$. Такая проволока может быть использована для упрочняющей наплавки деталей, работающих в условиях большого фрикционного нагружения.
\end{abstract}

Ключевые слова: наплавка; боридно-нитридные соединения; структура; твердость; износостойкость.

E.N. Yeryomin, Dr.Sc.Tech., A.S. Losev, Engineer, I.A. Ponomaryov, Engineer, S.A. Borodikhin, Engineer (Omsk State Technical University (OmSTU), 11, Mir Avenue, Omsk, 644050)

\title{
Technological increase of adhesive wear-resistance of parts added with chromium powder wire alloyed with complex of boron and nitrogen compounds
}

It is shown that the structure of metal padded with powder wire having the following mixture: $15 \% \mathrm{Cr}-0,5 \% \mathrm{~B}{ }_{4} \mathrm{C}-0,5 \%$ $B N-2,5 \% \mathrm{TiB}_{2}-1,0 \% \mathrm{ZrB}{ }_{2}$, is a martensitic matrix with $(\mathrm{Fe}, \mathrm{Cr})_{2} \mathrm{~B}$ boride eutectic, carbon boride of $(\mathrm{Fe}, \mathrm{Cr})_{7}(\mathrm{C}, \mathrm{B})_{3}$ type and $\varepsilon-(\mathrm{Fe}, \mathrm{Cr})_{2-3} \mathrm{~N}$ nitrides. Such a wire can be used for strengthening weld deposition of parts operated under conditions of heavy friction loading.

Keywords: weld deposition; boride-nitride compounds; structure; hardness; wear-resistance.

\section{Введение}

Одним из интенсивно развивающихся направлений в области упрочнения быстроизнашивающихся деталей и элементов оборудования является наплавка [1]. Долговечность работы значительной группы оборудования определяется сопротивлением коррозионному воздействию. Большими возможностями создания коррозионных покрытий обладает наплавка высокохромистыми порошковыми проволоками. В тоже время большинство таких покрытий имеют высокую коррозионную стойкость, но недостаточную износостойкость в условиях фрикционного нагружения.

* Исследование выполнено за счет гранта Российского научного фонда (проект №17-19-01224)
Одним из эффективных методов упрочнения металла является легирование его такими соединениями бора, как ферробор, карбид бора, диборид хрома, диборид титана [1]. Ранее выполненными исследованиями авторов установлено положительное влияние диборидов титана и циркония на износостойкость хромоникелевых мартенситностареющих сталей, наплавленных порошковыми проволоками [2]. Довольно широкое применение для легирования коррозионностойких сталей нашел азот [3]. В тоже время при наплавке азот вводят в металл за счет использования в порошковых проволоках азотированного хрома или феррохрома. Вместе с тем, для этих целей возможно использование нитрида бора, являющегося вследствие сходства ряда свойств электрон- 
ным аналогом углерода [4]. Однако нитрид бора в порошковых проволоках используется крайне редко.

Авторами показана перспективность применения наплавочной порошковой проволоки, легированной комплексом $\mathrm{B}_{4} \mathrm{C}-\mathrm{BN}-\mathrm{TiB}_{2}-\mathrm{ZrB}_{2}$ [5].

В тоже время современное состояние проблемы изнашивания требует знаний основных закономерностей упрочнения и разрушения поверхностных слоев металла при его фрикционном нагружении.

Исходя из этого, целью настоящей работы является исследование износостойкости и характеристик поверхности трения металла, наплавленного хромистой порошковой проволокой с комплексом соединений бора и азота.

\section{Методика проведения экспериментальных исследований}

Исследовали влияние боридно-нитридного легирования на износостойкость, структуру, трибологические и дюрометрические свойства хромистой стали, полученной наплавкой порошковой проволокой состава: $15 \% \mathrm{Cr} ; 0,5 \%$ $\mathrm{B}_{4} \mathrm{C} ; 0,5 \% \mathrm{BN} ; 2,5 \% \mathrm{TiB}_{2} ; 1,0 \% \mathrm{ZrB}_{2}$. Для сравнения исследовали сталь без боридов. Наплавку осуществляли на пластины из стали Ст3 размером $200 \times 50 \times 10$ мм опытными порошковыми проволоками диаметром 2,4 мм в аргоне в три слоя.

Испытания в условиях адгезионного изнашивания пар металл-металл осуществляли при трении скольжения без смазки по схеме палец-вращающийся диск (контртело), на машине трения УМТ-2168. На диск производилась кольцевая наплавка покрытым электродом марки OK Weartrode 55 HD (70Х10ГС), обеспечивающего твердость металла покрытия 56...59 HRC. После шлифовки по наплавленному покрытию осуществлялся контакт с образцами в виде пальца, торец которого наплавлен исследуемым составом. Испытание проводили при нагрузке $\mathrm{F}=0,75$ кН и частоте вращения диска контртела 100 об/мин.

Металлографические исследования наплавленного металла проводили на оптическом микроскопе AXIO Observer A1m (Carl Zeiss). Микроструктура выявлялась химическим травлением в реактиве состава: $\mathrm{CuSO}_{4}-4$ г; $\mathrm{HCl}-20$ мл; $\mathrm{H}_{2} \mathrm{O}-20$ мл.

Дюрометрические исследования проводили на образцах из металла после наплавки с помощью твердомеров ТК-2 по методу Роквелла и Shimadzu HMV-2 по методу Виккерса.

Электронно-микроскопические исследования проводили на растровом электронном микроскопе JEOL JSM-6610-LV с приставкой Inca-350 энергодисперсионного анализа.

\section{Результаты исследований и их обсуждение}

Результаты испытаний на адгезионное изнашивание металла покрытий без боридов и легированного боридными соединениями приведены в табл. 1 и табл. 2. Основные трибологические свойства наплавленного металла исследуемых покрытий приведены в табл. 3.

Металл покрытия без боридов выдержал всего 600 оборотов при пути трения 226 м. Средний массовый износ образцов уже после 300 оборотов составляет 1,029 г. После 600 оборотов массовый износ составил уже 1,70 г, при этом износ по длине достиг 5,33 мм, значение которого сопоставимо с длиной наплавленной части пальца. Поэтому образцы были сняты с дальнейших испытаний.

Среднее значение относительного массового износа за испытание составило 0,0075 г/м. Массовый износ для пути трения в 113 м составил 0,674 г. Среднее значение линейного износа за испытание составило 0,0235 мм/м. В результате испытаний момент трения снизился с 23,709 Н·м (для пути трения 113 м) до 19,601 Н·м (для пути трения 226 м). Среднее значение момента трения за путь трения 226 м составило 21,634 Н·м. Коэффициент трения уменьшился с 0,504 (для пути трения 113 м) до 0,423 (для пути трения 226 м), а среднее значение за испытание составило 0,464.

Металл покрытия с боридами выдержал уже 1200 оборотов при пути трения 452,16 м, а затем образцы были сняты с дальнейших испытаний. Средний массовый износ образцов после 300 оборотов составил 0,382 г, после 600 оборотов составил 0,683 г, а после 900 оборотов достиг 1,13 г. После 1200 оборотов износ составил 1,531 г. Относительный износ несколько увеличился с 0,0034 г/м в начале пути трения до 0,0036 г/м в конце.

Среднее значение относительного массового износа за испытание составило 0,0034 г/м, что в 2,2 раза меньше чем у металла покрытия без боридов. При этом износ по длине достиг 3,9 мм. Среднее значение линейного износа составило $0,00862 \mathrm{Mм} / \mathrm{M}$, что в 2,7 раза меньше чем у металла покрытия без боридов. При этом момент трения возрос с 19,026 Н·м (для пути трения 113,04 м) до 20,910 Н·м (для пути трения 452,16 м). Среднее значение момента трения за путь трения 452,16 м составило $19,075 \mathrm{H} \cdot$ м. Коэффициент трения уменьшился с 0,390 (для пути трения 113,04 м) до 0,348 (для пути трения 452,16 м), и составил среднее значение при испытаниях на износ 0,364.

Дополнительную информацию о процессах разрушения поверхностных слоев исследуемых покрытий дает анализ их топографии (рис. 1). 
1. Массовый износ образцов металла, г

\begin{tabular}{|c|c|c|c|c|c|}
\hline \multirow{2}{*}{$\begin{array}{c}\text { Количество } \\
\text { оборотов }\end{array}$} & Образец 1 & Образец 2 & Образец 3 & $\begin{array}{c}\text { Среднее } \\
\text { значение }\end{array}$ & $\begin{array}{c}\text { Относительный } \\
\text { износ, г/м }\end{array}$ \\
\hline 0 0-300 & 0,965 & 1,1382 & 0,9861 & $\mathbf{1 , 0 2 9 7}$ & 0,0091 \\
\hline $300-600$ & 0,6443 & 0,7108 & 0,6670 & $\mathbf{0 , 6 7 4 0}$ & 0,0060 \\
\hline $\mathbf{0 - 6 0 0}$ & 1,6093 & 1,849 & 1,6531 & $\mathbf{1 , 7 0 3 8}$ & $\mathbf{0 , 0 0 7 5}$ \\
\hline Покрытие с бридами \\
\hline $0-300$ & 0,4292 & 0,3751 & 0,3429 & $\mathbf{0 , 3 8 2 4}$ & 0,0034 \\
\hline $300-600$ & 0,1714 & 0,3587 & 0,3722 & $\mathbf{0 , 3 0 0 8}$ & 0,0027 \\
\hline $600-900$ & 0,4173 & 0,4138 & 0,5101 & $\mathbf{0 , 4 4 7 1}$ & 0,0040 \\
\hline $900-1200$ & 0,4715 & 0,3179 & 0,415 & $\mathbf{0 , 4 0 1 5}$ & 0,0036 \\
\hline $\mathbf{0 - 1 2 0 0}$ & 1,4894 & 1,4655 & 1,6402 & $\mathbf{1 , 5 3 1 7}$ & $\mathbf{0 , 0 0 3 4}$ \\
\hline
\end{tabular}

2. Изменение по длине образца металла, мм

\begin{tabular}{|c|c|c|c|c|}
\hline \multirow{2}{*}{$\begin{array}{c}\text { Количество } \\
\text { оборотов }\end{array}$} & \multicolumn{4}{|c|}{ Покрытие без боридов } \\
\hline & Образец 1 & Образец 2 & Образец 3 & $\begin{array}{c}\text { Среднее } \\
\text { значение }\end{array}$ \\
\hline 0 & 18,1 & 18,03 & 18,06 & 18,063 \\
\hline 600 & 12,63 & 13,15 & 12,44 & 12,74 \\
\hline \multicolumn{5}{|c|}{ Износ по длине образцов без боридов, мм } \\
\hline $0-600$ & 5,47 & 4,88 & 5,62 & 5,323 \\
\hline \multicolumn{5}{|c|}{ Покрытие с боридами } \\
\hline 0 & 14,96 & 14,88 & 14,97 & 14,9367 \\
\hline 1200 & 11,14 & 11,18 & 10,79 & 11,0367 \\
\hline \multicolumn{5}{|c|}{ Износ по длине образцов с боридами, мм } \\
\hline $0-1200$ & 3,82 & 3,7 & 4,18 & 3,9 \\
\hline
\end{tabular}

\section{3. Трибологические свойства металла}

\begin{tabular}{|c|c|c|}
\hline \multirow{2}{*}{$\begin{array}{c}\text { Количество } \\
\text { оборотов }\end{array}$} & $\begin{array}{c}\text { Предрытие без боридов } \\
\text { значение } \\
\text { момента } \\
\text { трения, Н·м }\end{array}$ & $\begin{array}{c}\text { Коэффициент } \\
\text { трения }\end{array}$ \\
\hline $0-300$ & 23,709 & 0,504 \\
\hline $300-600$ & 19,601 & 0,423 \\
\hline $\mathbf{0 - 6 0 0}$ & $\mathbf{2 1 , 6 3 4}$ & $\mathbf{0 , 4 6 4}$ \\
\hline \multicolumn{2}{|c|}{ Покрытие с боридами } \\
\hline $0-300$ & 19,026 & 0,390 \\
\hline $300-600$ & 15,472 & 0,354 \\
\hline $600-900$ & 20,880 & 0,363 \\
\hline $900-1200$ & 20,910 & 0,348 \\
\hline $0-1200$ & $\mathbf{1 9 , 0 7 5}$ & $\mathbf{0 , 3 6 4}$ \\
\hline
\end{tabular}

Для образцов без боридов, прошедших испытание, в большей мере характерен бороздчатый с глубинными вырывами рельеф поверхности износа с присутствием как мелких, так и крупных частиц продуктов изнашивания (рис. $1, a)$, что свидетельствует о протекании процессов адгезионного схватывания контактирующих поверхностей, сопровождающихся их задиром и заеданием.

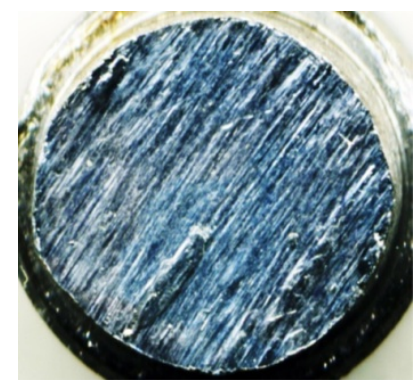

a)

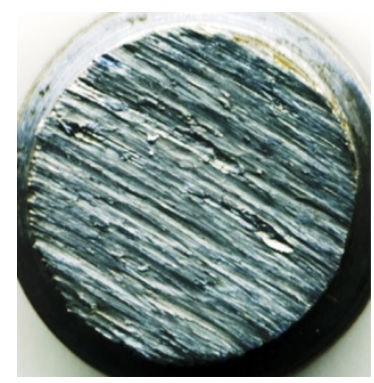

б)
Рис. 1. Поверхность торца образцов наплавленных покрытий после испытания на износ:

$a-$ без боридов; $\sigma-\mathrm{c}$ боридами

Покрытие без боридов с его относительно низкой твердостью ( $\approx 40 \mathrm{HRC})$ не обладает достаточным сопротивлением внедрению вершин микронеровностей контртела, что 
способствует высокой интенсивности изнашивания и повышенному коэффициенту трения за счет увеличенного числа очагов микросхватывания. Длительное фрикционное нагружение приводит к прогрессирующему разрыхлению поверхностного слоя металла, связанному с возрастанием числа очагов разрушения. Разрушение этого слоя приводит к катастрофическому изнашиванию, которое наблюдается после 226 м пути трения.

Для сопоставления результатов трибологических испытаний с микростроением поверхностных слоев при трении были проведены электронно-микроскопические исследования топографии образцов на характерных участках нагружения. Отмечается высокая степень фрагментации исследуемого материала за счет формирования полос скольжения (рис. 2).

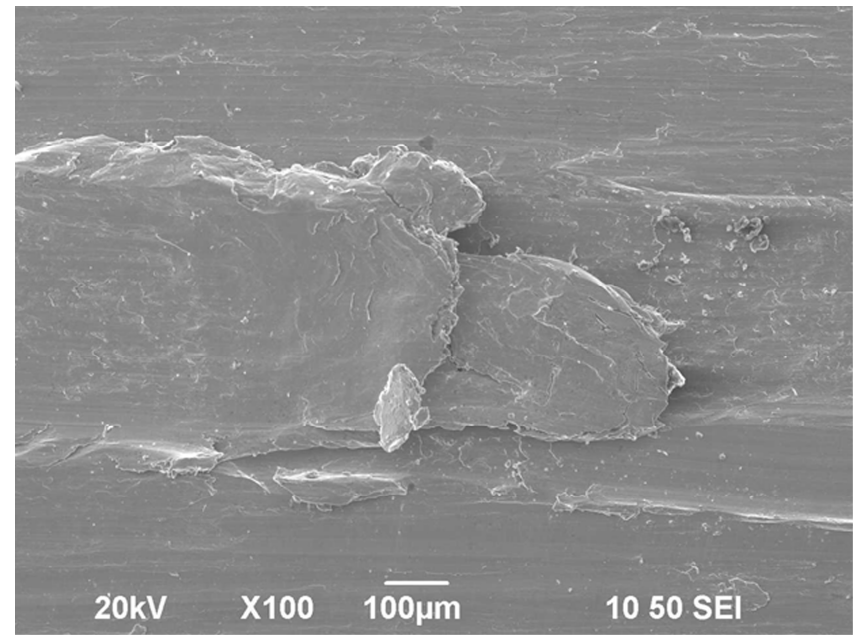

Рис. 2. Общий вид поверхности износа образца наплавленного покрытия без боридов

Микроструктура формирования этих полос скольжения характеризуется регулярным расположение дипольных дислокационных скоплений. Нагружение превращает эти полосы в очаги локализованной деформации в виде мезаполос. Этот процесс приобретает лавинообразный характер и приводит к селективным выбросам продуктов разрушения из зоны фрикционного контакта (рис. 3).

Проявляется локальный характер разрушения сколом по границам элементов субструктуры. Разрушение зоны фрикционного контакта характеризуется как глобальная потеря сдвиговой устойчивости поверхностного слоя после зарождения и движения мезополос локализованной пластической деформацией, что и обусловливает существенное изнашивание такого материала уже на малых путях трения.

Поверхность образца покрытия с боридами имеет относительно гладкий вид и характеризируется незначительными глубинными вы- рывами (рис. 1, б). Микроструктурные исследования металла образца после фрикционного нагружения обнаруживают формирование блочной структуры квазиравномерно распределенной по объему поверхностного слоя. В поверхностном слое реализуется, наряду с упрочнением, некоторая пластичность материала за счет высокой протяженности блочных границ и граничного проскальзывания. Одновременное измельчение блочной микроструктуры приводит к увеличению предела макроскопической упругости и сопротивления усталостному разрушению за счет уменьшения зернограничного растрескивания [6]. Отмечается сильная тенденция к текстурированнию дислокационных кластеров в одном направлении и развитию микрополос локализованной пластической деформацией (рис. 4).

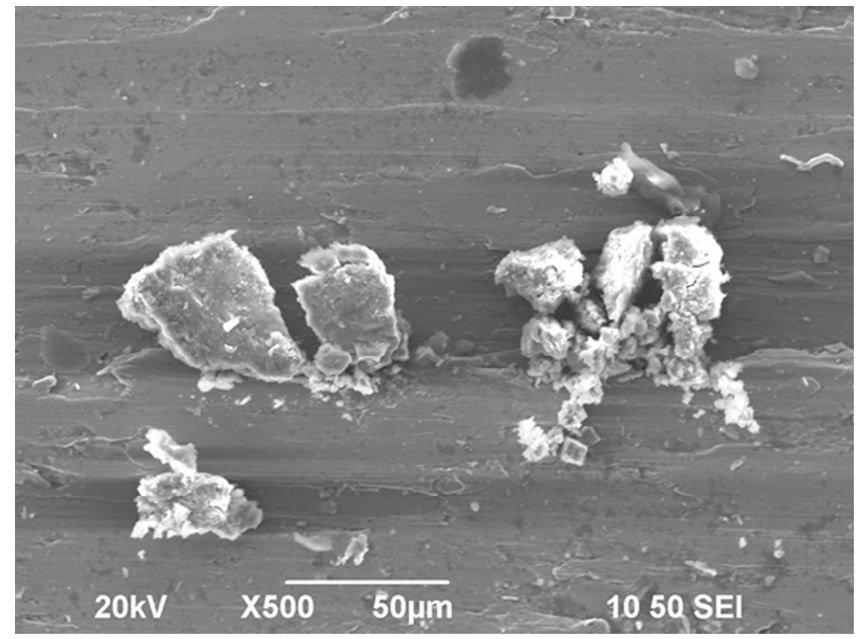

Рис. 3. Продукты разрушения в зоне фрикционного контакта образца наплавленного покрытия без боридов

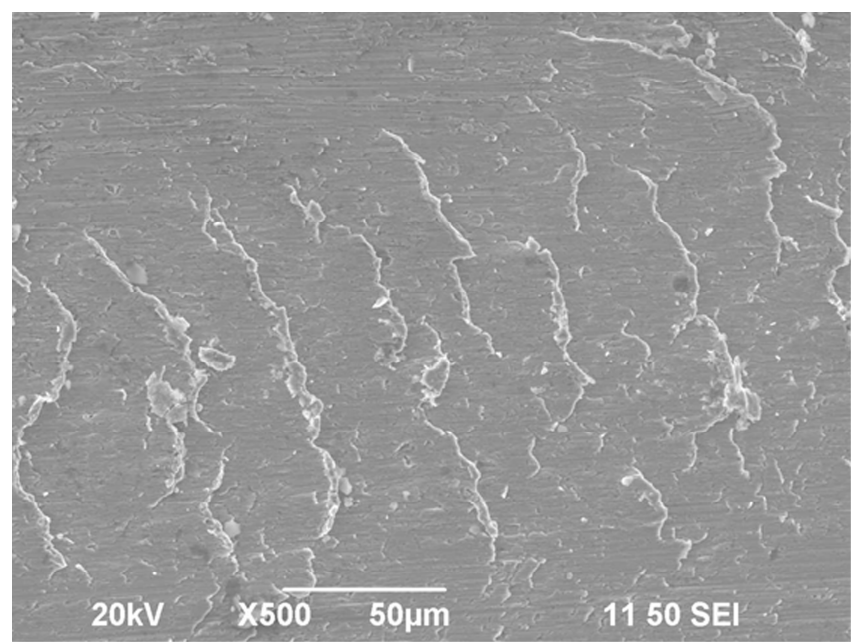

Рис. 4. Текстурирование блочной структуры металла образца наплавленного покрытия с боридами в процессе изнашивания 
В микроструктуре отмечено наличие мелких микротрещин, которые объединяются в магистральную трещину путем разрушения разделяющего их материала, формируя при этом лепестки изнашивания материала.

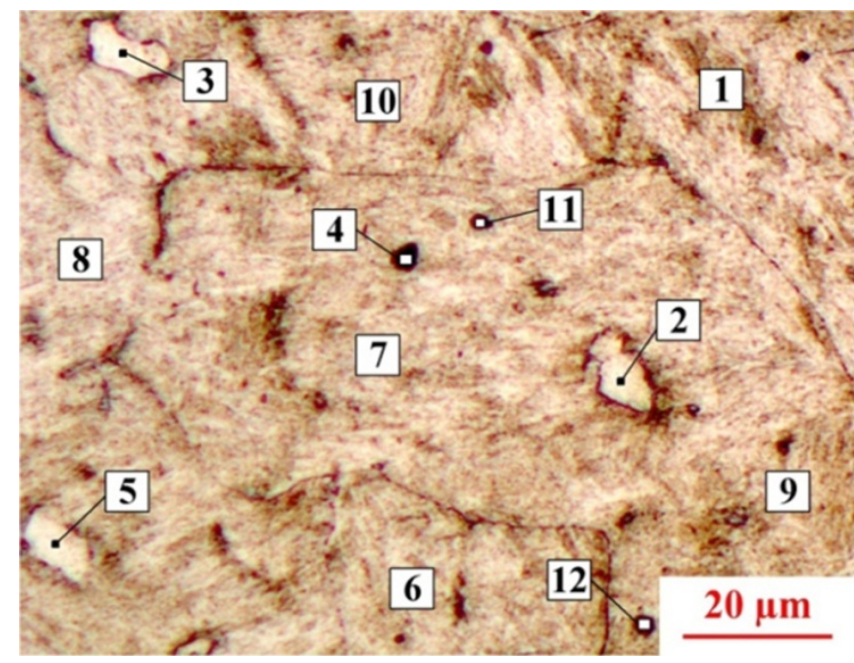

a)

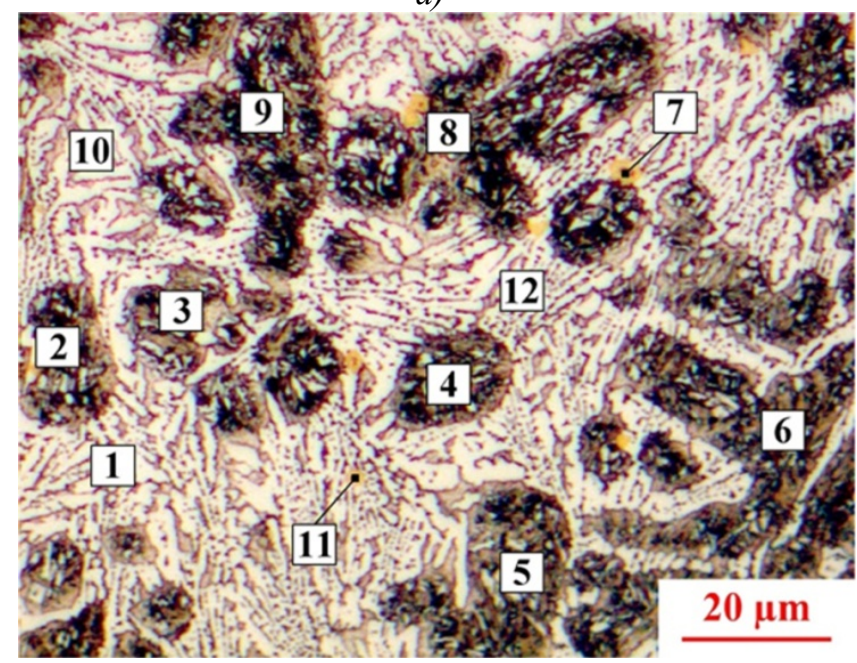

б)

Рис. 5. Изображение микроструктуры с распределением мест замера микротвердости составляющих металла покрытий, наплавленных порошковыми проволоками:

$a-$ без боридов; $\sigma-\mathrm{c}$ боридами
Для выявления причин различий в износостойкости покрытий, наплавленных порошковыми проволоками исследуемых составов, выполнен комплекс металло-графических и дюрометрических исследований.

Микроструктура металла, наплавленного проволокой без боридов, представляет собой смесь низкоуглеродистого мартенсита с высокодисперсным перлитом. По границам зерен наблюдаются выделения упрочняющих фаз, а внутри зерен $-\delta$-феррита (рис. $5, a$ ). Такая смешанная структура и обеспечивает твердость металла в пределах до $40 \mathrm{HRC}$.

Наплавленный металл покрытия с боридами имеет сложную композиционную структуру с мартенситной матрицей, большого количества эвтектики и частиц упрочняющих фаз (рис. 5, б). Твердость такого металла достигает максимального значения в $58 \mathrm{HRC}$.

Дюрометрические исследования показали существенные различия и в микротвердости структурных составляющих металла исследуемых покрытий (табл. 4).

Микротвердость матрицы металла без боридов изменяется от 390 до $430 \mathrm{HV}, \delta$-феррита от 358 до $384 \mathrm{HV}$, а упрочняющих фаз в пределах $550 \ldots 610 \mathrm{HV}$.

Микротвердость структурных составляющих металла, наплавленного порошковой проволокой с боридами, составляет для матрицы $521 \ldots 593 \mathrm{HV}$, эвтектики - 829...978 HV и упрочняющих фаз - 1262...1342 HV.

Для выявления механизма износа наплавленного металла покрытия с боридами проведены электронно-микроскопические исследования.

Результаты сканирующего электронномикроскопического анализа металла с боридами, структура которого приведена на рис. 6, сведены в табл. 5. Энерго-дисперсионный аннализ (ЭДА) показал, что структура металла представляет собой железо-хромистую мартенситную матрицу с эвтектической составляющей, образованной на базе борида $(\mathrm{Fe}, \mathrm{Cr})_{2} \mathrm{~B}$, имеющего каркасное строение, дисперсных включений карбоборидов типа $(\mathrm{Fe}, \mathrm{Cr})_{7}(\mathrm{C}, \mathrm{B})_{3}$ и высокопрочных нитридов $\varepsilon-(\mathrm{Fe}, \mathrm{Cr})_{2-3} \mathrm{~N}$.

\section{4. Микротвердость $\mathrm{HV}_{0,01}{ }^{*}$ и $\mathrm{HV}_{0,05}$ структурных составляющих металла покрытий, наплавленных порошковыми проволоками}

\begin{tabular}{|l|c|c|c|c|c|c|c|c|c|c|c|c|}
\hline № укола & 1 & $2^{*}$ & $3^{*}$ & $4^{*}$ & $5^{*}$ & 6 & 7 & 8 & 9 & 10 & $11^{*}$ & $12^{*}$ \\
\hline без боридов & 408 & 376 & 358 & 551 & 384 & 424 & 393 & 429 & 389 & 411 & 609 & 572 \\
\hline № укола & 1 & 2 & 3 & 4 & 5 & 6 & $7 *$ & 8 & 9 & 10 & $11 *$ & 12 \\
\hline с боридами & 978 & 587 & 540 & 552 & 575 & 546 & 1342 & 521 & 593 & 874 & 1262 & 829 \\
\hline
\end{tabular}

Изучение карт распределения основных элементов показало, что композиционная структура покрытия характеризуется наличием значительного количества дисперсных включений большей частью нитридов и карбидов титана и меньшей частью нитридов циркония размером от 0,2 до 3,4 мкм. 


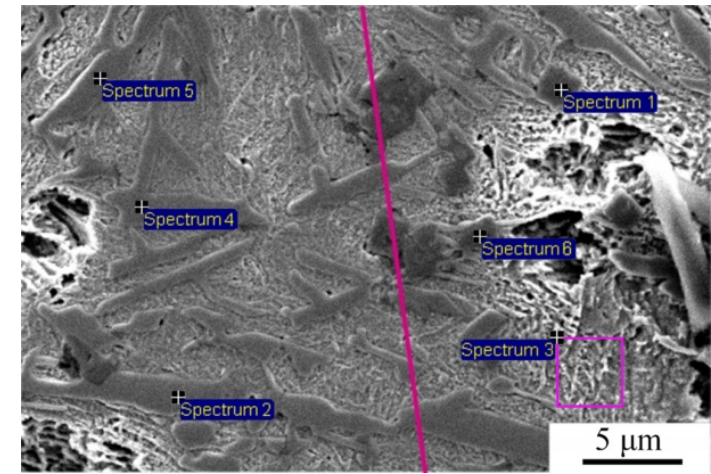

a)

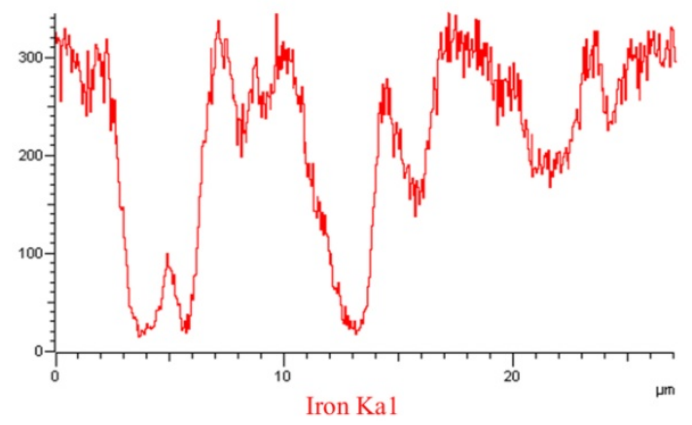

6)

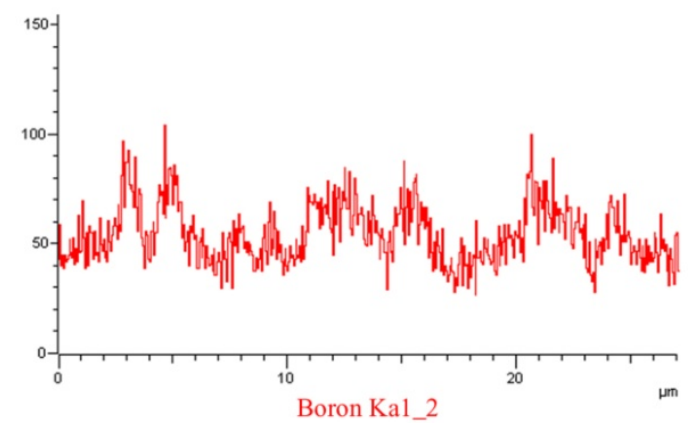

e)

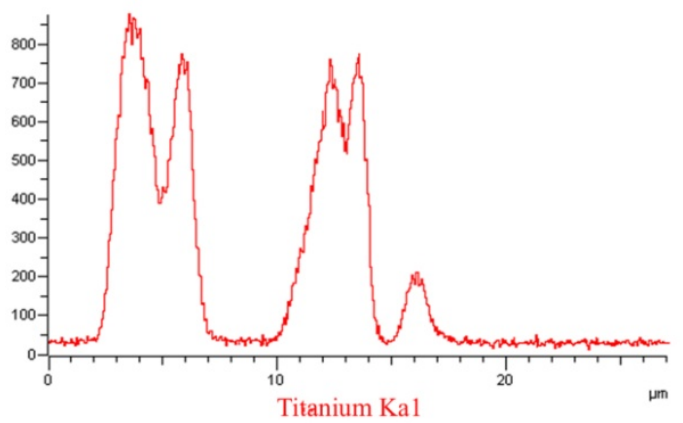

3)

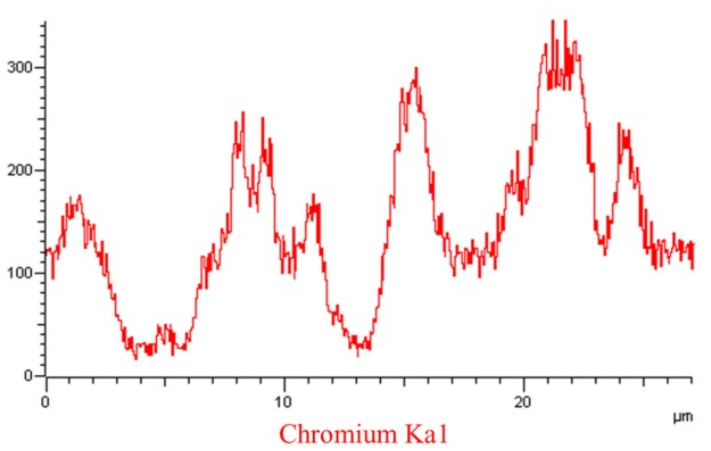

б)

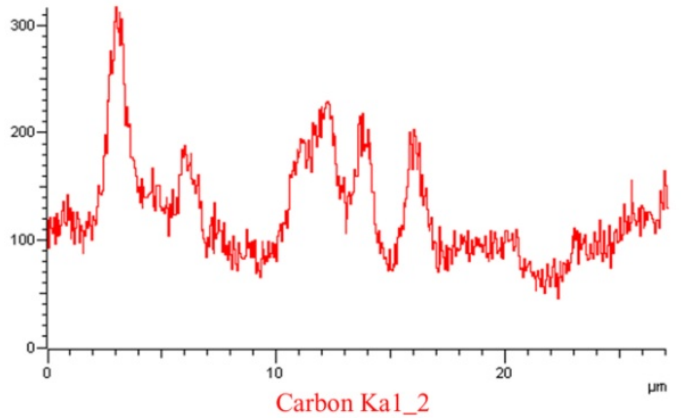

d)

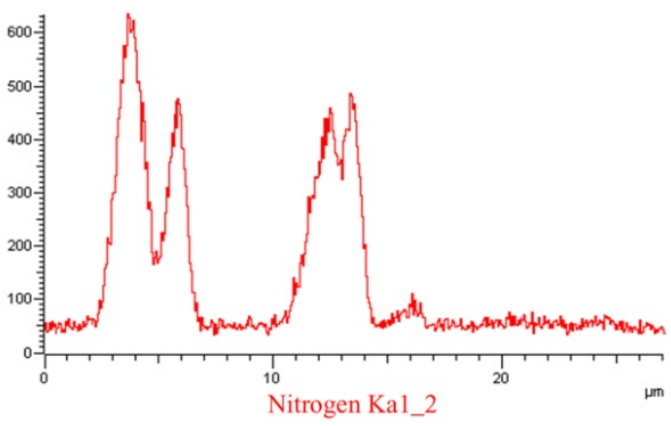

ж)

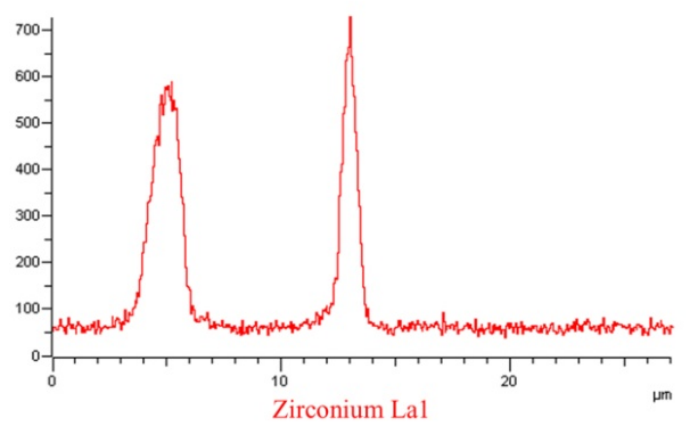

u)

Рис. 6. Исследование методом растровой электронной микроскопии структуры металла покрытия, наплавленного порошковой проволокой с боридами: $a$ - микроструктура с расположением областей сканирования методом ЭДА; $\sigma-u$-распределение элементов вдоль линии сканирования по данным ЭДА

Полученные результаты указывают на то, что механизм износа металла покрытия с боридами связан с его повышенной твердостью, обусловленной не только дисперсным упрочнением частицами боридных соединений, но и наличием боридной эвтектики, являющихся эффективными препятствиями для скольжения дислокаций в условиях пластического де- формирования поверхности при изнашивании [6]. Более высокую износостойкость металла с боридами можно объяснить совместным влиянием каркаса твердых эвтектических карбоборидов и частиц боридно-нитридно- и интерметаллидных соединений, которые в условиях абразивного изнашивания эффективно предохраняют матрицу покрытия. Как следствие, 
для изношенной поверхности такого металла характерны более слабые следы абразивного, адгезионного и глубинного разрушения, а также, незначительное смятие материала.

\section{5. Химический состав областей металла покрытия, наплавленного порошковой проволокой с боридами}

\begin{tabular}{|c|c|c|c|c|c|c|c|}
\hline Спектр & $\mathrm{B}, \%$ & $\mathrm{~N}, \%$ & $\mathrm{C}, \%$ & $\mathrm{Cr}, \%$ & $\mathrm{Fe}, \%$ & $\mathrm{Ti}, \%$ & $\mathrm{Zr}, \%$ \\
\hline 1 & 1,95 & 23,37 & 7,59 & 11,40 & 19,13 & 29,47 & 7,09 \\
\hline 2 & 24,32 & 0 & 5,32 & 24,92 & 45,22 & 0,17 & 0,05 \\
\hline 3 & 8,78 & 0,66 & 10,52 & 17,39 & 62,55 & 0,07 & 0,04 \\
\hline 4 & 5,65 & 1,37 & 7,77 & 15,08 & 70,03 & 0,06 & 0,04 \\
\hline 5 & 7,73 & 0,27 & 6,32 & 15,50 & 70,09 & 0,06 & 0,02 \\
\hline 6 & 2,96 & 20,75 & 9,16 & 16,48 & 10,45 & 31,16 & 9,04 \\
\hline
\end{tabular}

\section{Заключение}

Высокая износостойкость металла, наплавленного порошковой проволокой ППХ $15+0,5 \% \mathrm{~B}_{4} \mathrm{C}+0,5 \%+\mathrm{BN}+2,5 \% \mathrm{TiB}_{2}+1,0 \%$ $\mathrm{ZrB}_{2}$, объясняется наличием в его структуре каркаса твердых эвтектических карбоборидов и частиц карбидно-боридно-нитридно-интерметаллидных соединений, которые в условиях абразивного изнашивания воспринимают часть контактного взаимодействия, что увеличивает стойкость против задирания металла, работающего в условиях истирания. Видимо, это обусловлено тем, что дисперсные высокопрочные фазы являются эффективными препятствиями для скольжения дислокаций в поверхностных слоях металла при его фрикционном взаимодействии.

Таким образом, высокохромистая порошковая проволока, легированная комплексом соединений бора и азота, обеспечивает получение металла композиционного типа, обладающего высокой износостойкостью и может быть использована для упрочняющей наплавки деталей, работающих при больших фрикционных нагружениях.

\section{БИБЛИОГРАФИЧЕСКИЙ СПИСОК}

1. Шоев, А. Н. Наукоёмкие технологии нанесения покрытий // Наукоемкие технологии в машиностроении. 2012. - №11(17). - C. 27-33.

2. Eremin, E.N. Using boride compounds in flux-cored wires for depositing maraging steel // Welding International. 2013. - Vol. 27, No. 2. - P. 144-146.
3. Костина, М.В., Банных, О.А., Блинов, В.М. Хромистые коррозионностойкие стали, легированные азотом, новый класс конструкционных сталей // Технология металлов. -2000 . - № 10. - С. 2-12.

4. Курдюмов, А.В., Пилянкевич, А.Н. Фазовые превращения в углероде и нитриде бора. - Киев: Наук. думка, 1979. $-188 \mathrm{c}$.

5. Еремин, Е.Н., Лосев, А.С., Бородихин, С.А. Боридно-нитридное упрочнение металла наплавленного высокохромистой порошковой проволокой // Сварочное производство. - 2018. - № 7. - С. 3-8.

6. Pinchuk, V.G., Korotkevich, S.V. Physical patterns of dislocation structure kinetics in friction loaded surface layers // Global Journal For Research Analysis. -2015. - Vol. 4, No. 5. - P. 255-257.

\section{REFERENCES}

1. Shoev, A.N. Science intensive technologies of coating application // Science Intensive Technologies in Mechanical Engineering. - 2012. - No.11 (17). - pp. 27-33.

2. Eremin, E.N. Using boride compounds in flux-cored wires for depositing maraging steel // Welding International. 2013. - Vol. 27, No. 2. - P. 144-146.

3. Kostina, M.V., Bannykh, O.A., Blinov, V.M. Chromium corrosion resistant steels alloyed with nitrogen, new class of structural steels // Engineering Techniques. - 2000. - No.10. pp. 2-12.

4. Kurdyumov, A.V., Pilyankevich, A.N. Phase Transformations in Carbone and Boron Nitride. - Kiev: Scientific Thought, 1979. - pp. 188.

5. Yeryomin, E.N., Losev, A.S., Borodikhin, S.A. Boridenitride strengthening of metal padded with high-chromium powder wire // Welding Production. - 2018. - No.7 - pp. 3-8.

6. Pinchuk, V.G., Korotkevich, S.V. Physical patterns of dislocation structure kinetics in friction loaded surface layers // Global Journal For Research Analysis. -2015. - Vol. 4, No. 5. - P. 255-257.

Рецензент д.т.н. М.Г. Шальцин

Учредитель: Федеральное государственное бюджетное образовательное учреждение высшего образования "Брянский государственный технический университет"

Адрес редакции и издателя: 241035, Брянская область, г. Брянск, бульвар 50 лет Октября, 7 ФГБОУ ВО «Брянский государственный технический университет»

Телефон редакции журнала: 8-903-592-87-39. E-mail: naukatm@yandex.ru

Вёрстка А.А. Алисов. Технический редактор А.А. Алисов. Корректор Н.В. Дюбкова.

Сдано в набор 17.10.2019. Выход в свет 31.10.2019.

Формат $60 \times 88$ 1/8.Бумага офрсетная. Усл. печ. л. 5,88.

Тираж 500 экз. Свободная цена.

Отпечатано в лаборатории оперативной полиграфии

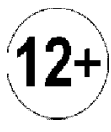

Федерального государственного бюджетного образовательного учреждения высшего образования

"Брянский государственный технический университет"

241035, Брянская область, г. Брянск, ул. Институтская, 16 